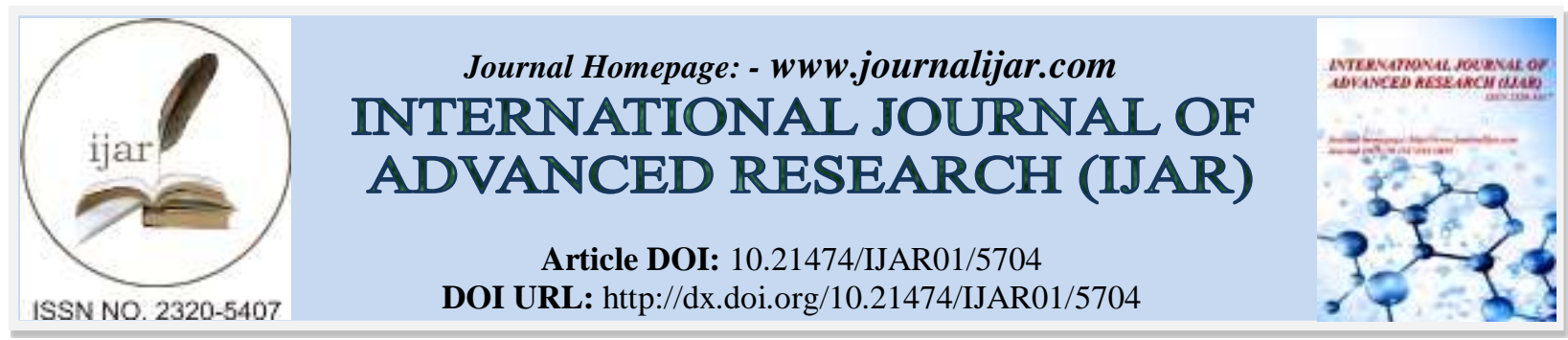

RESEARCH ARTICLE

\title{
SUFISM; THE DIVERSITY (KEBHINNEKAAN) LINK IN INDONESIA.
}

\author{
Syamsun Ni’am. \\ Faculty of Islamic Education and Teacher Training, Institut Agama Islam Negeri (IAIN) Tulungagung, \\ East Java, Indonesia.
}

\section{Manuscript Info}

Manuscript History

Received: 23 August 2017

Final Accepted: 25 September 2017

Published: October 2017

Key words:-

Sufism Diversity (Kebhinnekaan),

Islamization, Walisongo, and

Indonesia.

\begin{abstract}
Indonesia is a country of archipelago made up of thousands of small and large islands, stretches from Sabang to Merauke, and inhabited around 250 million people with diverse ethnic, racial, cultural, language, and religion. The majority religion of Indonesia is Islam. Even the world's largest religion as practiced by the inhabitants is Islam. In its long history, Islam came and developed in Indonesia peacefully, without violence at all. This happened because the Muslim preachers in spreading Islam always considered the local socio-cultural conditions, so that they - particularly Wali Songo in Java- were known accommodative and acculturative to the local culture. They were very aware of the diversity in Indonesia. The developed Islamic teachings were always discussed with the local socio-cultural conditions, so that Islam was easily accepted by the locals. The Muslim missionarist in Indonesia are the sufis who were known as the man who put forward the importance of tasamuh (tolerance), tafahum (understanding), tawasuth (harmonization), and tawazun (balanced). These universal values were then used as the basis to build a nation in the midst of diversity (kebhinnekaan) in Indonesia.
\end{abstract}

Copy Right, IJAR, 2017,. All rights reserved.

\section{Introduction:-}

In this paper, there are two key words that will be explained before discussed about the happenings related to the intent title above. The first key word is "sufism", ie a term in Islamic studies that is commensurate with the term "tauhid" and "shari'ah". Although in praxis, they look different in the meanings and emphasis. If the term "tauhid" emphasizes on the aspect of faith in belief in God, which is the embodiment of the concept "al-iman" itself; while the term "shari'ah" emphasizes on the aspect of outer (al-dzahir /exoteric) in religious practice through jurisprudence; then mysticism (sufism) emphasizes on the inner aspect (al-bathin/esoteric), due to the concerns about the understanding and teaching that arrange the direct relationship - even the unity- between God and human, so that the sufism life in the end is considered heavily laden with with nuances of private and individual.

Sufism in the public view is often identified with a static life, traditional, live alone, ignored (careless) with the hustle and frenzied world, indifferent to the changes, and various claims of stagnancy, though the assumption is not entirely true. Because on the one hand, although sufism (normatively and ideologically) looks static, but behind its stagnancy, it has kept a dynamism; so that in the long history of sufism, it is known there are some sufism movements; through individual figures (for example: Ibn 'Arabi, al-Hallaj, al-Jili, Jalal al-Din al-Rumi, al-Ghazali, Ibrahim ibn Adzham, etc.) -as well as organizational figures, for instance- through tarekat that emerged as a force 
that can move, not only motivate most of the people to fight against and repel invaders, but also can mobilize the masses in large numbers for the sake of the rule of law, social, culture, politics, and even economics.

While the second term which is the word "diversity (kebhinnekaan)" is taken from the word "diversity (bhinneka)", meaning "diverse" or different. The term of "neka" in Sanskrit word means "kinds" and becomes the word "aneka" in Indonesian (Hamim, 2001: 2). ${ }^{1}$ Thus, the "kebhinnekaan" referred to in the title of this article is diversity or difference concerning the aspects that contained and owned by the Indonesia community and the nation, either in relation to cultural diversity, ethnic, ethnicity, race, or religion. ${ }^{2}$ Then the next question is, where are the relationship between Sufism and diversity, as the title of this article? This will be discussed in the next discussion, that is how Sufism -as it is taught and practiced by Sufi figures in the past and present - can inspire the world view about the importance of building tolerance (tasamuh), understanding (tafahum), harmonization (tawasuth), and the balance (tawazun) in the center of diversity (kebhinnekaan) in Indonesia, without losing the values and principles of conscience and religion.

The review of sufism as a link for diversity (kebhinnekaan) in Indonesia, according to the author, is interesting to be discussed in this article because of several reasons: 1) Sufism emerges, grows and evolves with emerging, growth and development of Islam itself and in-context with socio-condition of local culture, so the sufism age is the age of Islamic itself; 2) the globalization and capitalization run magnificently with the passage of time and at the same time, all the consequences causing either positive (mashlahat) or negative (madharat), will follow behind. Therefore, sufism, which is an integral part of Islam -in addition to tauhid and shari'ah - must also participate in solving the problems of religious, humanitarian, and diversity as a bad result of modernization, to be used as an alternative solution to solve these problems, especially in Indonesia; 3 ) there is still misconception that sufism has been the cause of the backwardness of Muslims and the world, because its teachings are considered orthodox, static, and indifferent (careless) about life and change; 4) Indonesia is a nation-state, which has thousands of large and small islands, which stretches from Sabang to Merauke, with diverse religions, ethnicities, races, languages, and cultures. While the majority religion in Indonesian is Islam - even in quantity - as the largest Muslim in the world; and sufism is a domain that is taught in Islam. Therefore, sufism can be used in problem solving and religious diversity that could at any time appears to the surface; and 5) the spread of Islam, historically, always in dialogue and dialectic with the time and place at which it develops, and Islam is growing in Indonesia carried and spread by the majority of catering Sufi missionaries. In this case, Islam is like a snowball rolling and accompanying Islam journeys with the community and various things that surround it. Therefore, Indonesian Islam that is sufistic will always dialogue with culture, tradition, and various other diversity in Indonesia. Herein lies the significance of the study in this paper.

Sufism Makes Dialogue with the Time:-

Sufism is often seen as a form of Islamic spirituality in the sense of a spiritual path that is taken by a Muslim in order to attain enlightenment and secret association with the Khaliq (Allah). Based on this understanding, sufism is often referred to as Islamic mysticism (al-Qusyairi \& Haeri, 1993), even exclusively identified with the groups of tarekat that teach suluk practices in order to achieve their objectives. But many people forget that sufism is also a branch of the philosophy of Islam (al-hikmah), which has the basics own epistemology and methodology in seeking the truth. Unlike the two contemporary Islamic philosophy madzhab, ie rationalist and peripathetik, the search for truth through reason and critical reasoning alone, the sufi philosophy add another method that is unveiling inner (al-

1. In a furtper development, the term "bhinneka" is used as an idiom of nation and state in Indonesia with "Bhinneka Tunggal Ika". There are several terms that are understood differently by some countries. The difference occurs because the countries apply it differently as their principle. United States usually uses the term "Melting Pot Society", Canada uses "Multi Culturalism Community", India uses "A Composite Society", and Indonesia uses "Bhinneka Tunggal Ika".

2. The diversity (kebhinnekaan) here is not intended as a pluralism which is regarded as ideology that sees all religions are equal and can be mixed together. A pluralist often interprets the teachings of pluralism in the context of liberalism, while diversity (kebhinnekaan) here is intended merely recognition of the fact of social anthropologist in a society professing different religions. It is suggested by those who understand the diversity or pluralism of religion which is tolerance and the desire to be willing to coexist in communicative atmosphere. 
kashf), similar to the method used illuminative and intuitive that is used in madzhab mashriqiya (the oriental philosophy) Ibn Sina and ishraqiya (the illuminative philosophy) al-Suhrawardi al-Maqtul (al-Taftazani, 1983). ${ }^{3}$

In its long history, in the early days (the first century AH), sufism emerged in the East, and then spread to various parts of the world. Sufism also is a form of resistance against the spirit of rampant deviation of the teachings of Islam, especially conducted by the religious leaders at the time (Simuh, 1996). The result of the resistance, they formed - as Madjid Said - "pious opposition (opposition charged piety)" (Madjid, 2000), and always wanted to "imitate" as exemplified what the Prophet, especially by the companions of the Prophet (Simuh, 1996). For example, morale, simple life, mutual helps among others, compassion, and so on.

At that time, the sufism practice only became a political attitude toward political life that was chaotic, ie the occurrence of some political factions after the death of the Prophet Muhammad (peace be upon him). A number of people identified as the piety minded who tried to retreat from the political life that was uncertain, with only became closer to Allah. In the 3th - 9th century, sufism began to be taught openly in the center of Islamic Kingdom of Baghdad, then form a kind of popular religion which often had to deal with the religion of royal elites. At this time sufism experienced a shift from a political stance to fight against the rationale Islam that was the dominant in the 9th century to the 13th century AD.

At that time, Islam developed in a rational manner, so that it gave a high position on the mind role. The religious life at the time was dried dan less emosional. Since at that time, sufism had been a very strong appeal among the civil society. The sufism popularity as a popular religious movement had been the interest of the scholars to study various aspects of the orders (congregations) sufi that was widespread and replaced the function of other religious institutions, such as the government and the Islamic scholars, especially after the $13^{\text {th }}$ century AD when the Muslim world was destroyed by Mongol (Jamil, 2005).

The phenomenon of religious mysticism had become popular during 3/9th century. It is described by Fazlurrahman who offered the combination approaches. According to Fazlurrahman, there are several factors to explain this phenomenon; religious, social, and political. Sufism in the beginning teaches about individual piety in term of the communication between a slave and his God. The religious charm of this kind seems to carry the impression that there is a "religion in religion" with its idea structures, practices and organization. Through tarekat, sufism succeeded in formulating various stages in a neat and lead to a beginner student (salik) who must relinquish his humanity towards the divine natures. Such ideals charm continues to experience its growth despite opposition from the Islamic orthodox scholars, because they have an influence on the deviation that opposed to the initial ideals of sufism. This religious factors caused the disappearance of the Islamic resistance movement orthodoxy of sufism especially after 8/14 century AD.

Sufism - with its rites that are neatly organized and its meetings with the mystical orders - has socio-politically offered a pattern of social life that can meet social needs, especially of society who are uneducated. Through these sufism socio-religious groups, they connect to these professional organized groups. In Turkey, for example, in medieval times, the Sufi movement was intimately connected with the professional guilds and military organizations (Janissary). Even all work profession was often associated with the names of certain wali (sainthood). This appeared again in the life of sufism in Java, there is a book with title of the "Bisnis Kaum Sufi (Business of Sufis)" by Abdul Munir Mulkhan, which is the study of the trade tradition of the sufi in Kudus. Sufi is also defense against the state authorities, especially since the sixteenth century $5 / 11 \mathrm{M}$. when the Islamic union began to fade, and provide protection to the people due to the tyrannical power, which was precisely among the scholars of fiqh considered better than chaos and living without the law certainty. In addition to the case in Turkey, there is also another case in West and North Africa, and Eastern Sudan in modern times (al-Taftazani, 1983).

3. He is seen including one of the first generation of the sufi-philosopher. Full name al-Suhrawardi al-Maqtul is Abu al-Futuh ibn Habshi ibn Amrak, and is also known as al-Hakim. He is called al-Maqtul is to distinguish two other sufi, Abu al-Najib al-Suhrawardi (d. 563 AP) and Abu Hafsah Shihabuddin al-Suhrawardi al-Baghdadi (d. $632 \mathrm{AP}$ ), the compiler of al-Ma'a rif. The Opinions of al-Suhrawardi al-Maqtul about philosopher rank who is preoccupied divinity problems as well as research that is higher than the rank of the Prophet. This opinion, which led to harsh criticism against him from the fuqaha', of which from Ibn Taymiyyah (d. 727 AH), which launched allegations that the al-Suhrawardi claiming to be a proppet, and considered as the zindiq. 
As a form of spiritual knowledge that grows in Islam, sufism draws the attention of the Eastern religion and culture, as well as the Muslim experts in the 19th and 20th century, because some of its aspects are important and sufism is the only form of Islamic knowledge which focuses on inner dimensions (esoteric, mystical) of Islam, which is the inner dimension in relation to the dimensions of understanding (exoteric, formal) of the Islamic teachings. Therefore, it is not surprising when the issues concerning Islamic metaphysics, mystical experience, transcendental love, cosmology or spiritual formation of the universe in which man and the soul of man is included; and also the problems of psychology, epistemology and aesthetics become a major concern of the sufis fields in developing knowledge and appreciation of their religious foundation. Thereby, sufism not only contains religious values, but also contains norms and moral values of ethics, aesthetics, rationality, metaphysics, and even pedagogy, so Sufism is capable to have dialogue and dialectic with the conditions of its time (Ni'am, 2009).

\section{The Role of Sufi Figures in The Indonesian Islamization}

The Islamization process in Indonesia did not come into an empty "space" and condition. Islam came to a society that was already loaded with beliefs, traditions and practices of the previous lives. The community was not without a certain measure of morality, but on the contrary, it was inherent in their standard of values and morality. However, the standard of morality and values, at some particular stage, had been deviated. Therefore, it needed to be clarified by the new morality.

Related to the Islamization process in Indonesia, there is an opinion written by M. Solihin (Solihin, 2001). The first is the theory mentioned the Islamic history in Indonesia was an economic-business approach (trading). This theory is quite reasonable, because for a long time, the people of Indonesia had established trade with the Arab nations, Gujarat and China. The second is the theory of marriage approache, which is the immigrant and Muslim traders from the Middle East to establish a familial relationship with the locals. From this marriage, it produces a new generation of Muslims in Nusantara. The third is the theory of the political approach (power). The Political approach intended is $d a^{\prime}$ wah efforts undertaken by the Muslim merchants and immigrants who then managed to islamize the kings and the nobles, who previously embraced Hinduism or Buddhism. This theory seems to hold true after the establishment of Islamic governments in Nusantara, which is then managed to islamize the neighbor countries.

The fourth is the theory of the mystical approach. This theory is quite reasonable because the Muslim missionarists were ulama' who had knowledge and sufistic experience. They appeared as ulama' who practiced the sufi morality, even frequently lead and practiced specific tarekat. The clerics' appeared as charismatic sufi figures, dignified and wise, accommodating, and even compromised attitude toward the culture and local wisdom, also always uphold the values of the above examples. Therefore, without denying the other three approaches, the latter approach is more likely to be considered and acceptable. Because by looking at the figure of the Muslim Missionarist mentioned above. It has thus been recognized by the Orientalists, A.H. Johns acknowledged that it is a little possibility that if Islam came to Indonesia through trade approach. It is proposed a theory that the Sufi travellers that look more successful to perform the Islamic missionary in Indonesia.

The success of the Ulama'-sufi were very visible when there were many Sunni Muslims including ulama' and the Persia sufist (now Iran), who migrated to the new territories to be islamized due to the emergence of the uncertain political situation in the region. It could accelerate some other religion conversion to Islam, ie in the Indian Subcontinent, East and Southeast Europe, also Nusantara (Indonesia) in the period between the second half of the 10th century and the end of the 13th century. The whole process has contributed to the revival of the Hodgson called the "internationalization (universalization)" Sunni Islam (Azra, 1998; Hodgson, 1974). The process of spreading Islam in Southeast Asian countries - particularly in Indonesia - that grew spectacularly is a fact that can not be denied either by the historians or researchers. This is because the attitude shown by the sufis who were full of compassion, compromise, and more insightful local wisdom. Alwi Shihab noted that sufism has a human tendency that is open and cosmopolitan orientation (Shihab, 2001).

The statement is not exaggeration, as we have seen many sufi figures with distinctive attitudes and behavior, helpful, love, a sense of togetherness and true brotherhood among diverse societies (bhinneka), even more egalitarian and inclusive, in facing the local cultures and traditions. Therefore the sufis were very preferred and close to the grassroots, in addition to accommodating attitude and conformism that they had. This is why Islam quickly spread throughout Nusantara peacefully, without violence (civil penetration). They struggled to spread Islam because the call of conscience that is the duty and responsibility as a true believer, without expecting any reward or profit, and 
pure divine call. As described al-Qur'an: "Those who are not deterred by the trade and sale to remain in a relationship with God" (Qs an-Nur, 24: 37).

Abbas Mahmud al-Aqqad as quoted by Alwi Shihab illustrated, that "perhaps this Indonesian archipelagos are the most qualified place to attest to the fact that Islam is accepted and thrive in the midst of people who profess other religions. In every corner of the country there is clear evidence of how the Muslim missionarists spread Islam without using violence" (al-Aqqad, 1954). This proves that the Muslim missionarists had been aware of the sociocultural and socio-psychological Indonesian society, so the approach and methods used were very suitable and preferred by the Indonesian society.

The face of Islam Nusantara (Indonesia), is diverse, with the different patterns and understanding (bhinneka) as well as their religion, race, ethnicity, and culture. Indonesian Muslims in understanding the religions and beliefs are also diverse. However, as recognized by Martin van Bruinessen, there is one aspect that is very prominent in the Indonesian history. Martin said: "The thread of the mystical necklace is so strong to tie Islam! The earliest Indonesian Muslim works have sufism spirit, therefore they embraced Islam. Islamization of Indonesia began in the time when sufism was the dominant patterns of thought in the Islamic world. The prominent sufi thoughts, - such as Ibn al-'Arabi and Abu Hamid al-Ghazali- were very influential to the first Muslims generation authors in Indonesia. Moreover, almost all authors had also become a follower of orders" (Bruinessen, 1996). Thus, among the historians and orientalist researchers, and the Indonesia intellectuals as well, there was no difference to recognize that the sufis and their teachings became the most important factor in the process of Islamization in Indonesia. Even so, it is still found some doubt views of sufism, particularly in Indonesia. An Orientalist -Snouck Hurgronje for example-, said that although sufism has a significant role in the Islamization process in Indonesia, the teachings are nothing more than a bid/'ah and tales that have nothing to do with shari'at. Snouck further stated that the Indonesian Muslims respected sufism because the remnants of their Hinduism beliefs still attached, so that it became a determining factor for the success of the sufis in the Islamization process in Indonesia (Shihab, 2001).

In this regard, Martin noted that until the late 19th century, an opinion appeared that Indonesia was not a real Muslim (like Arabs), and under their small Islamic understanding, the Indonesian personality was formed and because it also was influenced by their previous religions (Hinduism, Buddhism and various forms of animism). Martin cites a Protestant evangelist, Poensen, who worked for decades in East Java, wrote in 1883, that the majority of the population claimed to be Muslims, but "somethings that they knew about were that Islam is only about circumcision, fasting, pork is haram eaten, the great festival and festival Mulud, and several other festivals". More Martin said that on the surface, the Javanese people were Muslim, but "inside their souls, other sprituality was still alive, and it stretched and expressed in a variety of forms and views, which obviously was not Islam; the indonesian people did not live and think Islamicly" (Bruinessen, 1996). However, Alwi Shihab (2001) gave a dissenting opinion. He said that the priori views above is not appropriate and invent. He argues several arguments. First, if we imagined that Islam was similar or even identical to those Hindu-Buddhist beliefs, of course it would be more appropriate to be the failure factor of the Islam message, because if it happend, the Indonesian people did not see the advantages and benefits of the Islamic teachings. So what it is for any conversion to Islam if ultimately the Islamic teachings were same as their beliefs.

Second, there were some efforts of the rebellion of Sheikh Nuruddin al-Raniri against the pantheism teachings of Hamzah Fansuri and Shamsuddin al-Sumatrani in the 17th century, which was considered the sufism misuse, even considered misleading zindiq. He wrote a book "Hujjat al-Shiddiq fi Daf'i Zindiq. If so, why the al-Raniri work was not used as a reference in describing the attitude and role of the sufis in the Islamization process in Indonesia.

Third, it is not accurate to claim that Hamzah Fansuri and his followers were influenced by the Hindu-Buddhist beliefs. However, they were influenced by the teachings of the sufis such as al-Hallaj, Ibn 'Arabi, al-Suhrawardi, and Jalal al-Din al-Rumi who were philosophically oriented. When the conception was found that there is a conflict with the beliefs of Islam, it is not a substantial opposition, but the expression of appreciation of faith in the new form or one type of expression. According to al-Ghazali, sometimes two streams can be met in a similar goal, and this does not necessarily mean that one is affected by the other or one plagiarizes another, but the meeting is often determined by the similar psychological factors ('Aun, 1983).

Thus, there is no doubt at all, that the role of the sufis in spreading Islam in Indonesia has a special place. Let it be assumed, that if it were not for the sufis as a propagator and preacher of Islam in Indonesia is, perhaps, the face of 
Islam in Indonesia will not be seen as we see today, which is Islam with tolerance, accommodating, compromistic, and inclusive. While in subsequent developments, the face of Islam in Indonesia, it seems to experience some changes as the global and local world have changed. Is it the face of Islam fundamentalist, leberalis, or moderate.

\section{The Diversity (Kebhninnekaan) According to The Sufi:-}

Idris Shah, a contemporary mystic, recounts in his work, a story about a sufi; there are four men, consisting of Persian, Turkish, Arabic, and Greek. The four men had traveled far down the towns and villages to the outposts. To unwind, they rest on the edge of a village. In the rest, they discussed about the rest of the money stock still in their pocket. Each of them wanted to buy something that was considered very important to take:

The Persian said, "I want to buy wine!"

The Turkish wanted to buy uzum.

The Arab wanted to buy 'inab.

The Greece wanted to buy stafil.

When the four men argued and even fought, suddenly a linguist came. The linguist was stunned to see the four men quarreled. He looked for to understand the conflict. Once he understood it, he asked for a coin that was owned by the four men, he said, "Give me your coins, I will try to meet your needs!"

In the begining, the four men suspected the linguist and they were anxious to be lied to. Once they heard the explanation, and he convinced them, the four men believed the linguists was a good person. With a sense of hope, the four men handed their coins to the linguists and the linguists went into a store and came back with a bunch of four wines.

"Well this is a wine that I want!" Said the Persian.

"This is what I call uzum!" Said the Turk.

"Thanks to you for 'inab!" Said the Arab.

"Yes, this is what I call stafil!" Said the Greek.

Then the wine was given to them, and they finally realized what they were arguing about the language differences, but the essence what they want was same.

Idris Shah continued his story, that the four men are people in general who come from different language backgrounds and from different cultures. Their problems are solved in the hands of a brilliant linguist, who later became known as a sufi. The public are conscious, that they want something, and there is the same inner need in themselves. They give different names, but the real essence is the same. Religion is a name that varies according to its adherents, perhaps even different ideas, and a different way. Let thus, because like that, it is prepared. However, it is important that they can enjoy the wines with gusto and refreshing (Shah, 2000; Ali, 2012; Bahri, 2010).

In the sufi's view, what in the world is the visible symbols of sightings (tajalli) God. Because God wants to know the image of Himself through His creation. In other words, the nature of the universe (cosmos) is a reflection of God himself. Therefore, In the sufi's view, whatever appears on this earth is only artificial from an actual fact. The world is a mirage (shadow) of the essential (true), that is the Creator of all that exists, that is God Almighty. Although in reality, religion, culture, customs, and the other else in appearance and different naming, because the aspects of the socio-cultural and contextualization, so that it could influence it, but the essence of the ultimate goal is the same, which is to obtain the eternal happiness (intrinsic). The Eternal happiness according to sufis, is quiet and peaceful heart when you can frolic with the beloved, whos is Allah SWT, even human could be together and united with Him.

The real meaning from what appears on the symbols in the world is the essence of truth. Therefore, according to the world view, it is good, but in the God's view fits to His will. Only certain groups who can understand the esoteric meaning of the symbols that appear earlier. Jalaluddin Rumi expressed in a poem:

"What will we do, O Muslims?

I do not know myself.

I'm not a Christian, nor Jew, not Jabr, nor a Muslim.

I'm not East, not West, nor sea, nor ocean.

I'm not earth, not water, not air, nor fire.

I'm not dust, not the existence, nor the entity.

I'm not an Indian, not Chinese, not Bulgarian, nor Saqsin.

I'm not the Iraq kingdom, nor the land of Khorasan. 
I am not this world, not going to come, not heaven, nor hell.

I'm not Adam, not Eve, not the Garden of Eden, nor the angel of Ridwan.

I do not take place, shapeless.

My body does not have a soul; I only have the spirit of Lover" (Bahri, 2010; Nicholson, 1975; Shah, 2000) .

Rumi seemed to provide an understanding of the world picture, which is basically has the same position in the eyes of God. Naming the outer is the true reality of the Most existence, who is Lord, even naming and appearance are different. The difference is only artificial difference such as an ilusion and ephemeral (nisbi).

Another figure who has a multicultural view is al-Hallaj (d. 922). It is narrated, once Abdullah ibn Tahir al-Azda told a story: "I had a fight with the Jews in Baghdad market and out of my mouth the words:" Hi dog! 'By chance alHallaj came along and looked at me with furious rage, and he said: 'Do not bring your dogs'. Then he quickly went. After completion of a fight, I looked for al-Hallaj. Apparently he welcomed me very well. I was giving him the reason of my fight. Then he said: 'O my son, all religions belong to Allah. He establishes a religion for each group, and they do not have the ability to choose, but it has been chosen for him. Therefore, whoever is to blame any religious groups, then he has punished these people who embraced the religions on their own efforts. Look! Religions: Judaism, Christianity, Islam, and so on, are different in the titles and the names that keep changing, especially when their goals are not different even they are diverse (Bahri, 2010).

In addition to al-Hallaj, another sufi figure who has diversity views is Muhy al-Din ibn 'Arabi. He has the same view with the previous figure, but with a different expression. His view is reflected in the theory of "God who is believed (Ilah al-mu'taqad)", which is also called "God in faith (al-Ilah fi al-i'tiqad)", or "God who is believed (alHaqq al-i'tiqad) ", or" God created the trust (al-Haqq al-makhluq al-i'tiqad) "."God who is believed "is God in knowledge, concepts, interception, or human perception. This God is not a God as He really is, but God's creation of man, the God who is created bythe knowledge, concepts, interception, or human perception. The God like this is "inserted" or "placed" by a man in his beliefs. "The shape, image or face" (God like this) is defined or characterized by the people who have faith in Him. "What is known" is characterized by "who knows". It is as al-Junaid said, "water color is the color of the bowl that is placed (lawn al-ma' lawn ina'ihi)". Therefore, God said: "I live in the thought of My servant (Ana 'inda dzanni 'abdi bi)". That is, God allegedly, is not known.

The true knowledge of God, according to Ibn 'Arabi is, knowledge that is not bound by a particular form of belief or religion. That is the knowledge possessed by the sufis. Therefore, the Sufis never reject God in faith, sect, denomination, or any religion. This means, that the God for the sufis, in all faiths, sects, denomination, or religion, is one and the same. Ibn 'Arabi said: "Whoever frees God of restrictions, will not deny Him and acknowledge Him in every form where He changes Himself (Bahri, 2010).

The other sufi figures who have pluralistic and inclusive views as sufi figures previously mentioned, among others, are Dara Shikoh (1615-1659), a sufi of the Qadiri Order, which bridge the gap between Islam and Hinduism. In addition, there is also sufis such as: Hazrat Inayat Khan (1882-1927), who received training in the Chistiyya Naqsyabandiyah, Qadiriyah, and Suhrawardiyah congregations. There is also a sufi, such as Bawa Muhaiyaddeen, a sufi from Sri Lanka. His interesting view is that any religion but Islam in fact is Islam, as long as this religion teaches faith in the one God, although it is not formally called by the word "Islam". He said: "Truth is one and Islam is one. It does not show preference to religion, sect, race, or a particular tribe". According Muhaiyaddeen, "truth is God himself" (Bahri, 2010).

Thus, - according to the sufis - what appears in the world, is not important. However, the most important of which is the essence behind it. This then sufis are almost always different in content and interpretation of the verses of alQuran and al-Hadith. Where sufis interpret the verses of al-Quran and al-Hadith with intuitive approach (Kashfi), which is unveiling behind these verses and more emphasis on the aspect of a substance that is behind the texts of the verse. Instead, the scholars of jurisprudence interpret the verses of al-Quran and al-Hadith, by using an literal approach, anything that sounded in the verse, is the belief in interpreting and giving contents. This later became the cause of never ending differencesthat happened in the Islamic thought history in the Middle Ages, the contradiction between the scholars of figh (textual) and sufi (substansialist).

The diversity for the sufis, is a necessity (sunnatullah) that can not be avoided or eliminated. Because it is a desire and will of God. Anyone who tries to escape from it even, he is considered a denial of sunnatullah. There are a lot of verses of the Koran and the Hadith of the Prophet which describe this diversity (kebhinnekaan), for example in 
the Qur'an, al-Hujurat: 13, states: “O mankind! Indeed, We created you from a male and a female and We made you nations and tribes that you may know one another. Indeed, (the) most noble of you near Allah (is the) most righteous of you. Indeed, Allah (is) All-Knower, All-Aware".

The sufi sees diversity as sunnatullah that can not be avoided, as the manifestation of God's own self-image (tajalliyat kamali Ilahiyyat). The sufi view can not be separated from the basic concept of faith as the foundation of ethics, aesthetics, and epistem. Because tauhid perceives that God is the epicenter of all existence, so the diversity (kebhinnekaan) that is in the earth, is a part of the rarity of the Essence of the Supreme One, the Lord Himself. If it is found that a variety of different shapes and different, it actually will return to the Almighty One. This viewmakes Islam as a religion that teaches about universalism. Therefore, there is someperennial philosophy figures like A.K. Comaraswamy, R. Guenon, F. Schuon, Seyyed Hossein Nasr, Titus Burckhard and others, they consider sufism as the most qualified representative of Islam to serve as a reference for the universalism understanding.

Throughout the Islamic history, it shows that sufism has always been at the vanguard of Islam in dialogue with other religions and other cultures. According to Seyyed Hosein Nasr, in the sufis view, the different religions are understood as a solar system in their respective places, each with its sun. A prophet or founder of a particular religion, is the sun in solar system, while the other prophets can be seen as the stars that are scattered in the sky and only visible at night (Nasr, 1980).

But among the stars, there is actually the sun in the solar system. Therefore, Rumi said: "The faith is a lot, but the confidenceis only one; the container of belief is many, but the soul of the beliefs is one. The soul of the beleivers is whole and one, because the soul ismore hundreds times than his bodies. Like a lightin the sky; its light is thousands times brighter than the light of thehome yard (Hadi, 2014).

The sufis views actually depart from the basic idea, which is the monotheistic view (tauhid). It states that God is the basis of all things, both visible and concealed. This is the basis for most of the sufi to look at the world of diversity in existence. The Diversity (kebhinnekaan) which appeared in the world is considered as God's tajalli Himslef. This view provides the understanding that the diversity that exists, whether religious, ethnic, ethnicity, race, tradition, and others, does not mean scattered or many kinds, which then lead to different interests, and lead to conflict (discord). However, the diversity that comes into the world, is a reflection of God's creation is deliberately exposed in accordance with His will, which will be returned to His Almighty One.

\section{Sufism is a Diversity (Kebhinnekaan) Link in Indonesia:-}

Indonesia as a plural and multicultural nation on one side will be a powerful force when the existence of each social element is appreciated and given the opportunity to develop, so that each element will enrich social and cultural treasures. On the other hand, the plural and multicultural conditions are going to be a destructive force, when the state prioritizes one group, whether based on ethnicity, culture or religion over other groups, so that each element does not have an equal opportunity to develop. Therefore, we must learn from the traditions that have ever lived and developed by our ancestors, grandparents, so the conflicts-particularly related to - tribe, religion, race, and the inter-tribe - can be eliminated; even these traditions can be a potential for the future development of the nation.

A tradition that has been growing is a tradition that takes insight and moderate understanding about Islam. This moderate tradition actually hasbeen passed and developed by our ancestors who spread Islam in Indonesia until today. The moderate traditions of the Islamic understanding that is pluralist, accommodating, and inclusive in Indonesia and become historical and morphed into the recesses of the people's lives in Nusantara. As we have been taught and developed by the first Islamic preachers in Nusantara, who are the sufis in Nusantara. The Nusantara sufis are the sufis who learned of the traditions that have been developed by the previous sufi figures.

We all understand and acknowledge that Indonesia is a nation state. It is large and diverse, with a total of tens of thousands of islands, stretching from Sabang to Merauke, 265 million of people, equipped also with ethnic diversity, culture, ethnicity, and religion. The socio-culture will bring a number of potential that can be used as a supporting or even become an obstacle to the progress of the nation (the positive and negative potentials). Therefore, there are two reasons why we treat and develop a moderate Islam understanding; The first, the pluralistic society will become a powerful force, when the existence of each social element is appreciated and given the opportunity to grow, so their each element will enrich social and cultural treasures. In contrast, the condition of plurality would be a destructive 
force, when the state prioritizes one group, whether based on ethnicity, culture or religion over other groups, so that each element has an equal opportunity to develop themselves.

The second reason refers to the dimensions of the nation's future that is characterized by globalization. In the global era, on the one hand, the relations among nations-including the interaction between interreligious people- will be more intense because of the support device transport technology, communication technology, and information technology. The good, people, and, services traffic will become intensive and boost recognition of the diverse cultural identities. On the other hand, these conditions can blind themselves to a variety of diverse global cultural reality, begets attitudes that nullify exclusive range of social reality and culminate in an effort to fertilize the exclusive ideologies. From here, it is possible that the social conflicts suddenly can come to the surface, so it can distort the brotherhood between the citizens and the internal —including inter religious communities.

Sensible sufi Islam as mentioned above, actually it is not difficult to find a reference in the Islamic history, either in the original territory of Islam itself or in Indonesia. More precisely, the Islamic sufi teachings — which is more moderate and inklusif - can refer to theplace where Islam was born, and the Islamicpractices that were taught by the Prophet Muhammad and his companions, especially al-Khulafa' al-Rashidun; where the Prophet Muhammad SAW. was developing social and cultural interaction in an egalitarian with various groups at that time. After the Prophet preached his prophetic mission "la ilaha illallah" in Mecca, he moved to the city of Medina, which was previously Yasrib. The Yasrib's name was given to the first person who came and built the city was Yasrib bin Amliq ibn Lauz ibn Sham ibn Nuh. The Yasrib community was quite diverse and familiar with pluralism. There was some dominant tribes that inhabited the city; the Aus, Khazraj, Qainuqa, Quraidlah, and Bani Nadzir tribes. The religion was also very diverse; Muslim, Jewish and little bit of Najran Christian. In the Muslim community itself, there are two kinds of groups which werethe migrants group who called Muhajirin (the original tribes of Mecca and its surroundings) and the local population, who ussually was called the Ansharin group (dominated by Aws and Khazraj tribes). While the Jewish group was derived from Nadzir, Qainuqa, and Quraidlah.

Here the Prophet SAW. had built a civilization by making interactions and communication with various parties. The Prophet himself never discriminated against any religion and group that were there, including against Islam itself. He always build the foundations of the importance of ethics and moral foundation in forming civilized people, who uphold the values of justice, freedom, equality of rights and obligations, and equal treatment under the law. To realize this, he formed a "State of Medina". This concept is then contained in the "Shahifah Madinah (Charter of Medina)" (Hisham, 341-343; Watt, 22-25), containing the ethical and moral principles. Here the Prophet by shariah (clear and firm) had instilled the values of humanism, egalitarianism, respect for diversity, mutual respect, interreligious, inter-ethnic and ethnicity respect, as well as existing groups. Thus, under any argument and reason, any violence in the name of anything, it will not be found at all its ethical foundation.

While the teaching about kebhinnekaan (respect for diversity that exists among the people) in the Indonesian context can refer to the Islam missionarists who are known as "Wali Songo". The generation that brought sufism in Indonesia has shown convincing evidence, that the sufi Islam is an Islamic teaching and education model that are consistent with the Indonesian society culture. The education and teaching model of Wali Songo were later adopted by pesantren that are scattered across Indonesia (Dhofier, 1994; Steenbink, 1994). ${ }^{4}$ Islam in the Indonesian context is close to -according to Shafi'i Maarif's concept-, "practicing Islam in the Indonesian Frame" (Ma'arif, 2009). Azyumardi Azra also frequently mentions that moderate Islam taught by Wali Songo is the original character of Muslim diversity in Indonesia (Basya, 2012).

4. The word pesantren is derived from the word santri, that is the prefix pe and suffix of an in front that means the residence of the students. Professor Johns argues that the pesantren term is derived from the Tamil language, which means tutor. While C.C. Berg believes that the pesantren term is derived from the shastri term which in India means a person who knows the sacred books of Hinduism, or, a Hindu scholar of religious scriptures. The shastri word comes from the word shastra meaning the holy book, religious books or books about science. In this regard, Karel A. Steenbrink, argues that pesantren is a traditional Islamic institution in Indonesia. The institution teaching focuses on religious instruction and uses traditional teaching methods and has special rules, administration, curriculum and teaching specialties. Pesantren is usually led by a religious teacher or scholar who is also a lecturer of the students. 
Pesantren as the miniature of Indonesian Muslim community has shown their roles in articulating a moderate Islam - which is taken from the sufism messages - in Nusantara. ${ }^{5}$ The Moderate Islam such as pesantren is then used as a base to spread Islam in a friendly way all over the world. In this regard, there are some traditions that have long been shown by pesantren where it is the oldest educational institution in the dynamic development of the Indonesian history. Based on the results of some studies conducted by the researchers, pesantren - or similar to it, such as surau, dayah and other names depend on the regions - has shown that since the beginning of its development (early 16th century), the Islam propagation adapted a friendly and easy way with Nusantara's culture and characters. As the oldest Islamic educational institution, pesantren has a major role in the process of Islamization (including cultural Islamization) in Indonesia, and even in Southeast Asia (Basha, 2012; Kompas, 10 Maret 2015; Jawa Pos, 10 Maret 2015).

The pesantren's ability adapted easily to the Nusantara characters which are diverse, and not oppressed with the progress of time. It is enough evidence that pesantren had stepped up and processed openly to difference and diversity (kebhinnekaan). The interesting dissertation of field research by Prof. Lukens-Bull (1997) from Arizona State University (ASU) AS., has supported this evidence, that the pesantren has created a new identity. They reject two forms of imitation which are Kamal al-Taturk's imitation, and the rejection form of Khomeini against everything from Western and modern world; pesantren community is aware and sensitive to globalization and McDonalization, but it remains actively respond to the globalization with peace jihad of pesantren teachings (Mas'udi, 1985).

The story of the sufis exemplary above — from al-Hallaj, ibn 'Arabi, Jalal al-Din Rumi, Dara Shikoh, Muhaiyaddeen, Hazrat Inayat Khan, and continued by Wali Songo in Indonesia- is a historical evidence to show that sufism has had a significant role in building the civilization of the world, introducing the universalism and egalitarianism values, Islam as a religion of mercy (compassion and peace). In the Indonesian context, the teachings of sufism developed by the sufis can be used as an entry point to unravel tangled thread of the diversity (kebhinnekaan) in Indonesia. The religious teachings of mercy and friendly brought by the sufis are an acculturative and accommodating religious model without distorting the essence of faith itself. This model of religion is suitable to be developed in Indonesia, when the world is faced with the challenge of global geopolitical phenomena such "ISIS (Islamic State of Iraq and Syria)" and the "Je Suis Charlie" movement in response to the terror of the Charlie Hebdo magazine in Paris. This is a clear example of civilizations conflict of extremities due to the weak interaction of ethics and respect for diversity and human values (Nuh, 2015).

\section{Conclusion:-}

The spectacular sufi story with the views and actions taken in building civilization of the world is very impressive. All of that is because the profile and performance have the charming appeal, along with the acculturative and accommodating behavior without depriving the root principle, which is tauhid as the basis of mystical view. Therefore, every step and charm brought by the sufis is always a positive impact in society, so that most people especially Nusantara people - greatly admired them, which was then easily lured to follow and perform religious conversion. It is this image that the subsequent development of a portrait of interaction and communication in accordance with its plural and multicultural society, as characterized by Indonesian society today.

Wali Songo is a pioneer in the development of sufi Islam in Indonesia - especially in the first Javanese, who have managed to instill the humanity and kebhinnekaan values (diversity and religiousity) in plural and multicultural society, so that the teachings about respects among the fellows with a multi cultural, ethnic, pattern, diversity, religion, and language, can be applied in the community, nation, and state. There is no doubt that the understanding of sufi Islam that is very close with moderate understanding - in which contains tasamuh (tolerance), tafahum (understanding), tawasuth (harmonization), and tawazun (balanced) values - taught by Wali Songo and their successors, it can be used as an alternative solution in solving the pluralism and diversity (kebhinnekaan) problems in Indonesia.

5. It cant be denied that pesantren tends to be less moderate. This then led to the emergence irrelevant comments against the existence of pesantren. For example pesantren of Al-Iman Ngruki Solo that is led by Ustadz Abu Bakar Ba'ashir; Pesantren Al-Islam, in Kampung malang, Solokuro, Lamongan, East Java; Pesantren of Umar bin Khattab, Bima, West Nusa Tenggara, and others. Even Yusuf Kalla, when he was at charge of the Vice President, had proposed to close these pesantren that taught allegedly hardness values. 


\section{References:-}

1. Ali, Yunasril. 2012. Sufisme dan Pluralisme: Memahami Hakikat Agama dan Relasi Agama-Agama. Jakarta: PT. Elex Media Komputindo.

2. Al-Aqqad, Abbas Mahmud. 1954. Al-Islam fi al-Qarn al-'Ishrin: Hadlirihi wa Mustaqbalihi. Kairo: Dar alKutub al-Haditsah.

3. Aun, Faisal Badr. 1983. Al-Tashawwuf al-Islami al-Thariq wa al-Rijal. Kairo: Maktab Sa'id Ra'fat.

4. Azra, Azyumardi. 1998. Jaringan Ulama Timur Tengah dan Kepulauan Nusantara Abad XVII dan XVIII: Melacak Akar-akar Pembaruan Pemikiran Islam di Indonesia. Bandung: Mizan.

5. Bahri, Media Zainul. 2010. Tasawuf Mendamaikan Dunia. Jakarta: Erlangga.

6. Basya, M. Hilaly. 2012. Menelusuri Artikulasi Islam Moderat di Indonesia. Available at: http://www.madinask.com/index.php?option=com. Retrieved on 15 March 2012.

7. Bruinessen, Martin Van. 1996. Tarekat Naqshabandiyah di Indonesia. Bandung: Mizan.

8. Dhofier, Zamakhsyari. 1994. Tradisi Pesantren: Studi tentang Pandangan Hidup Kyai. Jakarta: LP3ES.

9. Hadi, Abdul, W. M. 2014. Kebhinekaan Beragama dalam Perspektif Tasawuf. Available at: http://ahmadsamantho.wordpress.com/2010/12/14/kebhinekaan-agama-dalam-pandangan-ahli-tasawuf. Retrieved on 24 June 2014.

10. Haeri, Syaikh Fadhlalla. 1993. The Elements of Sufism. Amerika Serikat: Element, Inc.

11. Hamim, Thoha. 2001. "Islam dan Hubungan Antar Umat Beragama". FORMA. XXVI: 2.

12. Hodgson, M.G.S. 1974. The Venture of Islam II. Chicago: Universty of Chicago Press.

13. Jamil, M. Muhsin. 2005. Tarekat dan Dinamika Sosial Politik; Tafsir Sosial Sufi Nusantara. Yogyakarta: Pustaka Pelajar.

14. Kompas, 10 Maret 2015.

15. Koran Sindo, 10 Maret 2015.

16. Ma'arif, Ahmad Syafi'i. 2009. Islam dalam Bingkai Keindonesiaan dan Kemanusiaan; Sebuah Refleksi Sejarah. Bandung: Mizan.

17. Madjid, Nurcholish. 2000. Islam Doktrin dan Peradaban: Sebuah Telaah Kritis tentang Masalah Keimanan, Kemanusiaan, dan Kemodernan. Jakarta: Paramadina.

18. Mas'udi, Masdar Farid. 1985. "Mengenal Pemikiran Kitab Kuning”. M. Dawam Rahardjo (ed). Pergulatan Pesantren: Membangun dari Bawah. Jakarta: Perhimpunan Pengembangan Pesantren dan Masyarakat (P3M).

19. Nasr, Seyyed Hossein. 1980. Living Sufism. London-Boston-Sidney: George Allen\& Unwin Ltd.

20. Ni'am, Syamsun. 2009. The Wisdom of K.H. Achmad Siddiq; Membumikan Tasawuf. Jakarta: Erlangga.

21. Nicholson, R.A. 1975. The Mystic of Islam. London: Routledge \& Kegan Paul.

22. Nuh, Mohammad. "Pengibar Bendera Rahmatan lil Alamin". Jawa Pos, 30 Januari 2015.

23. Al-Qusyairi, Abu al-Qasim. Al-Risalat al-Qusyairiyyah. Egypt: Dar al-Khair.

24. Shah, Idries. 2000. The Sufis. Translater M. Hidayatullah \& Roudlon. "Mahkota Sufi: Menembus Dunia Ekstra Dimensi". Surabaya: Risalah Gusti.

25. Shihab, Alwi. 2001. Islam Sufistik: "Islam Pertama” dan Pengaruhnya hingga Kini di Indonesia. Bandung: Mizan.

26. Simuh. 1996. Tasawuf dan Perkembangannya dalam Islam. Jakarta: P.T. Raja Grafindo Persada.

27. Solihin, M. 2001. Sejarah dan Pemikiran Tasawuf di Indonesia. Bandung: Pustaka Setia.

28. Steenbrink, Karel A. 1994. Pesantren, Madrasah, dan Sekolah: Pendidikan Islam dalam Kurun Moderen. Jakarta: LP3ES.

29. Al-Taftazani, Abu al-Wafa' al-Ghunaimi. 1983. Madkhal ila al-Tashawwuf al-Islami. Cairo: Dar al-Tsaqafah li al-Nasyr wa al-Tauzi'. 